\title{
The Impact of Political Authority on Building the Architectural Image
}

\author{
Basim Hasan Hashim Al-Majidi \\ Department of Architectural Engineering, University of technology \\ 90004@uotechnology.edu.iq
}

\begin{abstract}
Architectural studies differed about the concept of power in architecture according to the type of authority and the intellectual and theoretical orientations of these studies. Authority is one of the key factors influencing the formation of the identity of architecture.

The building has its image or the effective way in the formation of its distinctive civilization structure, hence the purpose of the serach study the relationship (political power architecture), and study the potential of power and its impact on the architectural image. Here, the problem of research can be determined by (the lack of clarity of the comprehensive conceptual perception of the political and material capabilities of authority in building the architectural image). In the research problem, deals with a comprehensive conceptual framework which has constructed by addressing a series of studies, researches and international experiences that have reflected the influence of political authority on building the image of architecture, and thus adopting the vocabulary derived from the theoretical framework in analyzing a number of international and Arab's projects that reflect the effective role of authority in building and shaping the architectural identity of those buildings in particular and their reflection on the city in general. The results of this application and conclusions have analyzed, which showed the intentionally effect of political authority on the general taste of the governed group, through the conscious imitation of the vocabulary, forms and relationships of the physical image used by the ruling authority as models of economic power and dominance. The results have showed this effect unconsciously which lead to the production of replicable models in different places or models. It has counted as symbols for a specific period of time and then turn into national symbols that form the starting point of an architectural identity that symbolizes this era.
\end{abstract}

Keywords: Political authority; Architectural image; Architectural identity.

Paper History: (Received:18-11-2018; Accepted:7-12019)

\section{Introduction}

each project consists of many activities and numerous items therefore to obtain the same level of quality in each item by different projects' parties such as designers, users, project owners is very difficult and may be impossible [1].
Political authority is one of the important factors in the ideological and intellectual change of architectural production, as it is a political witness and a record of political events and fluctuations, which embodies the power of the state and its authoritarian and political tendencies. It is the political power that governs the nature, movement, themes and planning of architecture. In general, the studies have highlighted four types of authority: the authority of the expert through his enactment of authority, the authority of the work through its narrative function, the authority of the design project through being a motivation for arousing and opening the field of narrative and interpretation, and finally the authority of text. Therefore, it has overlooked the role of the state and its political authority for achieving or changing the course of those types of authorities, and thus it draws and characterizes the features of the production in particular and the city in general. So, the research seeks in its aim for (building a cognitive perception for the most important influences of political authority in building the architectural image). Given the fact that the authority is a variable concept depending on the different criticism methodologies and multiple directions, the research methodology is as follows:

- Building a base of a comprehensive knowledge for the concept of the authority in general, and political authority in particular, with the aim of achieving the impact of the political authority states on the transformation of the architectural image for the recipient.

- Statement of the basic vocabulary for the theoretical framework of the concept of political power and its impact on shaping the image of architecture according to the rules, patterns and traditions of society.

- Test the vocabularies have derived from the theoretical framework in an intentional sample of selected international and Arab projects, and then extract, discuss, analyze the results and present the conclusions.

\section{Political Authority and the Potential of Materialism and Moralism}

\subsection{The Concept of Authority}

There are multiple meanings of authority whose denotations vary according to the place on which they are used. It is a personal and an individual authority to refer to a person's power and authority, which are necessarily 
absolute, whether he is a leader of a state or a political organization or a social movement. It may be used again to express certain functions of the state, especially when we talk about the three authorities, legislative, executive and the judicial authority. The researchers don't find any explicit reference to the word of authority, whether in the Kor'an or in the dictionaries of the Arabic language, what they have found the act of authorize, which carries the meaning of power, domination and oppression [2].

The Arab World Encyclopedia has defined authority in social sciences as the ability of individuals or groups to impose their will on others. Influential people can impose sanctions or threaten against those who do not obey their orders, and power is almost present in all human relations [3]. From this point of view, the concept of authority comes from Bourdeau as: it is a complex system that penetrates all interconnections and relations that operate internally through precise and effective mechanisms that control the general structure of that system. For this reason, Bourdeau is keen to connect them to the concepts of pattern, the field to which he belongs, which is of great importance in his intellectual project [4]. Stephen Wax has summed up the meaning of power and authority. Wax explains that the idea of power is the concept of achieving consequences, and that is about securing compliance or obeying. Compliance can be secured by the use of force or by the choice of people to surrender to others. When people choose to accept the will of others as legitimate or right, the relationship can be described here as one form of authority..Authority can take various forms in life including: religious authority, moral authority, academic authority, political power ... etc. [5].

Max Weber believes that there are three types of authority (traditional authority, legal - rationalism authority, and charismatic authority). Weber also assumes three main sources of legitimate authority (large community, small groups, or traditions within society), [6].

\subsection{Relationship of Authority and the Concepts of (Policy and Strategy)}

The concept of the word "siyasa", which means policy, in Arabic is a complex concept, as the word comes from the triple act of "sas", which means "tame". From the definition of the word policy in the tongue of the Arabs: policy is the act of the tamer. It is said that "he tames the animals" if he raises and tames them. The same word is used for the governor or the guardian "guides and tames his people". If we return to the definition of the word "policy" in ancient Semitic languages such as Phoenician, Aramaic or even Syriac, we see that these languages used a common definition of this word: "madinaio". The word "medinaio" is closely linked to the word "madina", which means city. From this word the other two words can be derived: "madania" which means civil, and "tamdun" which means civilization. This means that political action in ancient Semitic civilizations has primarily aimed at the city. This concept is radically different from the one that defines the relationship between the president and the subordinate, and the second definition is also related to the word "deen" which means religion, as the religion is the law that regulates religious relations in civil society.

Policy is also defined in the Webster Dictionary as a specific path or procedure chosen from among the alternatives under certain circumstances to guide and determine current and future decisions. It has also known as a comprehensive high-level plan that includes general objectives and acceptable procedures, particularly by the government agency [7].

Strategies: They are the means used to achieve the objectives and vision of the policy that has developed in advance. There are long, medium and short-term strategies. The strategy aims at mobilizing means, distributing roles and creating the physical and moral environments, thus the strategy is the practical motor environment for policy vision [8]. Note that the policy sets the appropriate strategy and determine future decisions according to alternatives to achieve its objectives.

\subsection{Architecture as a Political Witness}

Rushdie has said that political power is one of the important engines that shapes, forms or be the urban facade of the city through political times and periods. That is because most rulers have imposed their policies on all corners of the state, whether in the political, economic, social or urban. As the succession of political periods on the city has an active role in the formulation of new architecture, building the image of the city, the formation of its architectural facade through the occupancy of urban spaces and streets, and change the architectural features of buildings that form the urban fabric form, content, identity and layout [9].

Ahmed Waqee'a discusses the structure and deconstructing the architecture in an attempt to understand it, he has found through this deconstructing that the relationship between architecture and politics is based on three levels:

Level 1: Architecture is a political witness, at this level, architecture is a record of many political events that have passed through it, occurred in the architectural origin, or left its mark on it.

Level 2: the political symbolism of architecture, at this level, architecture embodies the power of the state and its political orientations, and this kind of architecture is common in Islamic architecture. This symbolism is expressed in a number of architectural expressions, some of which have civilian content and some are politically guaranteed. There are a number of buildings that combine these two types with multiple expressions.

Level 3: the intellectual relationship between politics and architecture, and this relationship is the one that governs the nature, themes, movement and planning of architecture, which stems from the political orientation of the authority. This approach is ideologically reflected in architecture in 
multiple images, it doesn't occur at once. It overlooks the phased architecture in order to gain it, when it is changing from pattern to other by changing authority, where a new architectural character is acquired, to know archaeologists and architects as the architectural style [10].

\subsection{Policy and the Pattern of History Production}

Many hypothesis suggest that society is not only based on the production and distribution of material resources that are governed and managed by politicians, but also by the society, which organizes other moral and symbolic activities. In each society there is a pattern of production of meaning, which in turn is divided into several sections and depending on the nature of the relationship related to the conditions and presences of production.

In relation to the production of meaning with the source, we talk about an ideal pattern (religious) or secular pattern (worldly). In terms of the relationship of meaning to the fields or areas that affect it, we talk about a pattern of philosophical, moral, political or religious production. While In relation to the individual or society we talk about an individual production pattern of meaning and a collective production pattern of meaning. History produces great things such as pyramids, magnificent churches, great mosques, palaces, schools, factories, statues and all that embodies the glories and history of the nations. But this bright face is matched by another grim face represented by the forms of war devastation. The bright face of history usually covers the other half. The question here: who fulfills this bright face of history? It focuses on those who contribute to the creation and formulation of major historical events, who produce society and history as much as society and history produce them. We are here talking about the relationship of history, whether with its actors or whom affected by, and that political ideology is the main engine of those architectural achievements [11].

As aforesaid, the procedural definition of political authority can be defined as the legal and legitimate ability to control the direction of others towards a certain thing in the light of reliance on knowledge, skill and certainty, which are essential elements on which political authority is based. The relationship of architecture with political authority is a relationship of forces affect and affected by certain actions and behavior through the violation and alteration of all internal relationships and associations by means of precise and effective mechanisms that control the general structure of the architecture in multiple images. It does not occur at once, but it overlooks the phased architecture in order to gain it.

\subsection{Authority and Building the Architectural Image}

\subsubsection{Image and Symbol}

The image in the human mind is a subjective simulation of forms and spaces, as well as the forms that exist in reality. This image will be present in mind even after its absence from the recipient, and it is a replica of reality. It is a coding of forms and elements as well as simulating the bonding relations of those elements [12].

Symbols are based on implicit connotations within the system of secondary meanings of forms and images that humans know with the basic meanings of these forms. This union is determined in different civilian and cultural contexts. Thus, the symbol is more comprehensive than the image, a creator for it, through the investment of the powers inherent in the symbol, and through the alienation of the image from the intellectual context 9 which seems to be not monolithic with it, which leads the symbol to create an atmosphere of codes and meanings that have a broad interpretation for the recipients [13].

\subsubsection{Authority and Building the Image}

The building of the architectural image is in the light of the processes of perception. The perception is either visual, which is achieved by the sensory mechanisms of human being in order to interpret and understand the surrounding environment, or to be mentally aware through the image of the thing in the mind, whether it is accompanied by emotion or not. Therefore, the examination, understanding, and building the image for the architecture require studies on whether these buildings in turn serve the community that built it or did not do so. studies shall be also about use of materials and the foundations of the structure, and the possibility of being considered a work of art helps to build symbols and identity of architecture and its image formation or not. Number of researchers have touched upon the building of the architectural image, including, as stated before, building the architectural image is based firstly on the type of perception and understanding that we carry about architecture and the human being as a designer and receiver, and the type of impression and special evaluation, which is the basis of the architecture to determine the changes that surround the architecture related to human being. Secondly, the scope of the designer's social and intellectual movement according to the following stages:

- The stage of dealing with philosophy of the idea of multiple architectural images as dealing with it in general.

- The ideological stage, which is the medium stage of dealing with architecture.

- The stage of proposals or alternatives as cases of solutions by presenting ideal results in adaptation according to conditional acceptance of what is typical [14].

In his book "The image of the city" Kevin Lynch explained that the architectural and urban image is constructed through mental mapping techniques as well as interviews with the population and has initially concerned with how to provide clarity, that is, how people guide themselves and guide their ways within the city. 
Lynch explained that the ease mentally organization of the environment is in the light of the interconnected schemes of any mental image of our ability to move easily within the environment. In his research, Lynch has started a secondary idea of orientation within the city to reach the basic idea of the mental image of the city. The observation of sectors, signs, paths, and clear-cut nodes in the city's master plan led to the definition of what Lynch has called the capacity to generate and construct an architectural and urban mental image. And defined it as the property of the physical object which gives it high possibility to raise a strong image of any observer or scenes. Despite his awareness that mental images can vary among different observers [15].

Lynch has tried to diagnose the overall picture of the city or its main components in light of the three main characteristics in building the architectural image of the city:

Identity: It distinguishes something from other things as an independent entity.

Structure: The space relationship of the object with the observer and other things.

Meaning: The meaning of the practical thing and the emotional impact on the observer.

Since it is unlikely that the meaning has the feature of stability at the city level and across the various groups of people, Lynch has separated the meaning from the figure, exploring the possibility of creating the image and building it according to the physical properties in relation to identity and structure. Through exercises to draw the mental map, it aims to diagnose the characteristics of the environment that left a strong image in the mind of the observers by assembling the individual mental image and the possibility of reaching a general image or the image of the city [16].

It is noted that the building of the architectural image is in light of the transition from the sense to the image of the object or building in mind and according to three laws that expand the circle of mental response and form the expression in the image of the architectural. These are three laws: the law of sensory or visual perception which is in the light of the perception of the building and its sense, and the law of perceiving the similarity through the use of figurative and expressive signs that convey meanings to the mind on the basis of similarity and external association in the understanding of others. Finally, the law of perception of the mind. The thing in mind is what he has found conditional and coupled with that in the light of the relationship between form and meaning. The building of the architectural image moves from simple formulas to more integrated formats and expansion in the accommodation of images and comprehensiveness of meanings and shapes.

Dargham al-Obeidi said that the political system that controls the various fields of life affects societies, by including architecture and urban design. The architectural products represented areas for ideological and intellectual change. They represent the formation of a different and distinct cultural pattern in the history of the growth and development of architectural thought. What the happens, of course, in the society of political, intellectual, scientific and social changes must find representation in the field of architecture and urban, and then occur in architecture change similar to change in the thought of society. As the architecture becomes the identity of that political, economic or social thought and then embodies the most important events, as well as being a historical and real indicator of that period of the life of society [17]. "Maroun Kassab" said that architecture in its popular sense today is concerned with the design of the building. It specializes in building design, civil design, garden design, infrastructure design, etc. In short, architecture is concerned with the design of human societies. If today's architectural disciplines are branching into the fields of education, then civilizational politics ignore ideological, doctrinal and religious differences. it will focus on the development of the city primarily, and civil relations within this civil framework. Here, the role of architecture as a means of pushing civil society and urbanization towards creating a structural system suitable for the human environment. Authoritarian change comes only through human will, but architecture is the vehicle that translates human will through the development of the structural environment and the provision of the urban system, in which human and civil relations interact [18].

It is clear then that the building of the architectural image is in the light of the political authoritarian change, which focuses on the development of the city and civil relations within this civilian framework. The role of architecture as a means of pushing the civil society and civilian society towards the creation of a structural system suitable for the human environment that translates all events, changes and fluctuations of political authoritarianism in an integrated system for the city. Architectural image interacts with human and civil relations to revive the concept of civilizational policy, and to restore the role of political action to take care of the affairs of the city and citizens and its relationship with civil society.

Therefore, the image can be defined as the shape or form, structure, or compositional structure, in which the city emerges, which results from the process of collecting elements, parts and vocabulary in the process of sensory or mental perception. The process of building the architectural image in the stage of sensory perception is by recognizing the clarity of the physical elements in the city like paths, edges, sectors, nodes, landmarks or signs as seen by the naked eye. While at the stage of mental perception, the formation of the architectural image of the city by drawing mental maps, and moving from the sense to form the image of the object in mind on the basis of the use of graphic and expressive signals that convey the meanings to mind in more integrated forms, and more expanded 
incomprehension of images, meanings and shapes, also expanding the extent of mental response and form the expression in the image of the architectural product, thus formation the image of the city by emphasis on identity, structure and meaning.

The role of authority in formation the architectural image is either explicit (physical), or implicit by influencing planning, management, governance, economics, architectural thought and directing social and cultural issues. The political authoritarian fluctuations have a role in adding new meaning to history, new perception of society, and a new structure for the city, it aims to achieve something out to reality, and emphasizing the architecture which based on tradition, context, environment, and history or other types that change the city's visible and hidden structure.

\subsection{Previous Studies}

A series of studies on the concept of power in general and its relation to the architectural image will be reviewed in order to build a comprehensive theoretical framework that includes the previous theoretical thesis and the results of the studies. In order to enrich the perception of the role of political authority in building the architectural image of the city. Table (1) shows a summary of some previous studies, their objectives, and the most important vocabularies derived from the

Table (1): Summary of Previous Studies and their Objectives, and the Most Important Vocabulary Derived from

\begin{tabular}{|c|c|c|c|}
\hline No. & Author - Study Title & $\begin{array}{l}\text { The main cognitive aspects } \\
\text { presented in the study }\end{array}$ & $\begin{array}{c}\text { The purpose of the study and the } \\
\text { vocabulary of the theoretical } \\
\text { framework }\end{array}$ \\
\hline $1-6-1$ & $\begin{array}{l}\text { Victor A. Pestoff, } \\
\text { 2009, entitled "A } \\
\text { Democratic } \\
\text { Architecture for the } \\
\text { Welfare State", [19] }\end{array}$ & $\begin{array}{l}\text { The study focused on the importance } \\
\text { of activating democracy and political } \\
\text { authority in building a social state } \\
\text { that enhances the well-being of the } \\
\text { population (welfare state) and } \\
\text { stressed the historical relationship } \\
\text { between the popular movements and } \\
\text { the third sector, on the one hand, and } \\
\text { the state on the other. }\end{array}$ & $\begin{array}{c}\text { - Focused on the development and } \\
\text { transformation of the public } \\
\text { sector and the changing luxury } \\
\text { mix between the public and } \\
\text { private sectors and the third } \\
\text { sector to provide social welfare } \\
\text { services. } \\
\text { - Developing new channels to } \\
\text { increase citizen participation }\end{array}$ \\
\hline $1-6-2$ & $\begin{array}{c}\text { Sylvain de } \\
\text { Bleeckere, } \\
\text { Universiteit Hasselt, } \\
\text { 2007, entitled " Style } \\
\text { and Architecture in } \\
\text { a Democratic } \\
\text { Perspective", [20] }\end{array}$ & $\begin{array}{l}\text { The study focused on the cultural } \\
\text { role that architecture can play for } \\
\text { shaping the ongoing process of } \\
\text { democratization in the world } \\
\text { community. } \\
\text { The "democratic approach" can help } \\
\text { to liberate the architecture from the } \\
\text { stylistic canonical obsession and } \\
\text { build a new image of architecture. } \\
\text { Highlights the relationship between } \\
\text { political democracy and pattern } \\
\text { (style). }\end{array}$ & $\begin{array}{l}\text { - Building a model and a new } \\
\text { image of architecture } \\
\text { - Creative democracy has a role in } \\
\text { educating "democratic } \\
\text { consciousness" } \\
\text { - The release of architecture from } \\
\text { the stylistic structure of } \\
\text { intellectual ecclesiastical } \\
\text { construction and the construction } \\
\text { of a new image of architecture }\end{array}$ \\
\hline $1-6-3$ & $\begin{array}{l}\text { "Dargham Mezher } \\
\text { Kareem Al-Obaidi, } \\
\text { 2012", entitled "The } \\
\text { Impact of Politics on } \\
\text { the Thought of } \\
\text { Architecture, An } \\
\text { Analytical and } \\
\text { descriptive Study of } \\
\text { the Influence of } \\
\text { Political Ideology on } \\
\text { the Achievement of } \\
\text { Architecture, Berlin, } \\
\text { [21] }\end{array}$ & $\begin{array}{l}\text { The study shows that the images of } \\
\text { the architectural products belong to a } \\
\text { number of periods, which represent } \\
\text { areas of ideological and intellectual } \\
\text { change, which occur at the level of } \\
\text { substance and are later embodied in } \\
\text { the formation of a distinctive and } \\
\text { different cultural pattern of sequence } \\
\text { of history of the development and } \\
\text { growth of architectural thought. }\end{array}$ & $\begin{array}{l}\text { - Culture and its role fpr building } \\
\text { the image of architecture } \\
\text { - The information network led to } \\
\text { the abolition of customs and } \\
\text { traditions, and receded. }\end{array}$ \\
\hline
\end{tabular}




\begin{tabular}{|c|c|c|c|}
\hline $1-6-4$ & $\begin{array}{l}\text { Ahmed Yahya } \\
\text { Rashed, 2003, } \\
\text { entitled } \\
\text { "Architectural } \\
\text { Education between } \\
\text { the Preservation of } \\
\text { Identity and the } \\
\text { Political Dimension: } \\
\text { A Study of the } \\
\text { Course of History } \\
\text { and theories of } \\
\text { Architecture from } \\
\text { the Beginning of } \\
\text { Human Civilizations } \\
\text { to the Age of } \\
\text { Globalization", [22] }\end{array}$ & $\begin{array}{l}\text { The study has showed that the } \\
\text { political and authoritative dimension } \\
\text { will give the power and power to the } \\
\text { owner of information and who is the } \\
\text { most capable and fastest in the } \\
\text { creation, processing and investment } \\
\text { of information and hence being the } \\
\text { reference and source in the } \\
\text { construction of new images for } \\
\text { architecture. This study aimed to } \\
\text { study the reciprocal interaction of } \\
\text { the influence of politics on } \\
\text { architecture and how politics are } \\
\text { affected by architecture and urban } \\
\text { heritage from the beginning of the } \\
\text { era of human civilizations until the } \\
\text { era of globalization. }\end{array}$ & $\begin{array}{l}\text { - contribute to install the concepts, } \\
\text { values and historical and future } \\
\text { rights of different peoples } \\
\text { - Building the image of } \\
\text { architecture through (identity, } \\
\text { direction and memory) } \\
\text { - Architecture Image tracks the } \\
\text { function } \\
\text { - Functional dimensions of the } \\
\text { language of architecture, namely } \\
\text { the formative dimension (or } \\
\text { formal structure and spatial } \\
\text { dimension), and the applied } \\
\text { dimension that determines the } \\
\text { diagnostic quality. }\end{array}$ \\
\hline $1-6-5$ & $\begin{array}{c}\text { Hassanine and } \\
\text { others study } 2015 \\
\text { (political } \\
\text { transformations and } \\
\text { their impact on the } \\
\text { architectural } \\
\text { character of } \\
\text { administrative } \\
\text { buildings in Egypt), } \\
{[23]}\end{array}$ & $\begin{array}{l}\text { The study has showed the mutual } \\
\text { influence between politics and } \\
\text { architecture through the impact of } \\
\text { political transformations on the } \\
\text { nature of architecture of } \\
\text { administrative buildings during the } \\
\text { 20th century }\end{array}$ & $\begin{array}{l}\text { - The ideological intellectual } \\
\text { approach and the capitalist and } \\
\text { socialist systems } \\
\text { - Economic situation, social } \\
\text { situation, cultural situation } \\
\text { - Selecting from heritage, } \\
\text { integrating heritage with } \\
\text { modernity. }\end{array}$ \\
\hline
\end{tabular}

The previous studies have shown the importance for solving the research problem, which is: (the lack of clarity of the comprehensive conceptual perception of the political and material capabilities of authority in building the architectural image). From the contents of the preceding paragraphs the theoretical framework will be put forward, and what is included in those studies of main or subvocabulary represents the first steps to solve the research problem.

\section{Theoretical Framework and General Applied Framework}

\subsection{The Abstracted Framework}

After identifying the most important aspects of the Authority, the abstracted indicators of the theoretical framework will be compiled, by identifying a set of main vocabularies, their indicators and related secondary vocabularies, which will be adopted in the practical study as shown in Table (2).

\subsection{Practical Study}

After the shows of the various cognitive studies on the subject of the basic research and the formation of the architectural image by adopting the effects of political power, and shows of previous studies that dealt with the subject directly or indirectly and formation of research problem and its purpose, in this section theoretical framework for the subject of research will be built. Samples for application will be elected for projects that political authority played a prominent role in its emergence. The research samples came in two groups, one international and the other is Arabian. Therefore, the theoretical knowledge of these samples will be introduced initially based on descriptive and criticism sources.

\subsection{Samples Selected for Application}

\subsubsection{First Group - Arab Projects}

\subsubsection{Al Arab Tower Hotel/ Jumeirah Beach Complex, 1997, Dubai Coast, by W.S. Atkins}

Al Arab Tower is now a distinctive feature of Dubai city. It is one of the three main elements of the Jumeirah Resort, namely the coast, Aqua Park, the Al Arab Tower Hotel. Located on the Arabian Gulf coast, it was built over seven years by W.S. Atkins and was completed in 1997, [24]. The Tower of Al Arab Hotel has a triangular plan consisting of two 320-meter high-rise residential parts as wings, consisting of 202 two-storey suites spread over 28 floors, as well as three restaurants, banqueting activities and a health club. These two wings are surrounded by an Atrium, They meet from one side with a central part of the concrete, including lifts, stairs and services [24]. The main objective of this tower has to emphasize the symbolic meanings associated with the city of Dubai so that it becomes a landmark for the world as a whole, and symbolizes economic strength and looking towards the future [24]. The architectural sources see that the designer has succeeded in achieving the goal at multiple levels. The architectural 
sources believe that the designer has succeeded in achieving the goal at multiple levels. It has chosen a unique form associated with local heritage on the one hand and global technological progress at the same time. The sail or mast form, known in the region as the Dhow, which faces the northeast and southwestern façade. From the south-east facade, the tower appears as a modern yacht. The high morphological form is related to the meanings of power, hegemony, reverence, exclusivity, a sense of luxury and technological progress [25]. On the site level, the unique site contributed to the emphasis on the monumental meanings. The hotel was built on a triangular artificial island, about 300 meters away from the land and connected with it by the bridge [25]. The building undoubtedly served as a cultural symbol that represents the interrelationship between global, western, technological and contemporary values on the one hand, and a reference to a part of the heritage of the region on the other, and a new custom that replaced old customs and took its place [26]. Figure 1 shows photos for Al Arab tower in Dubai
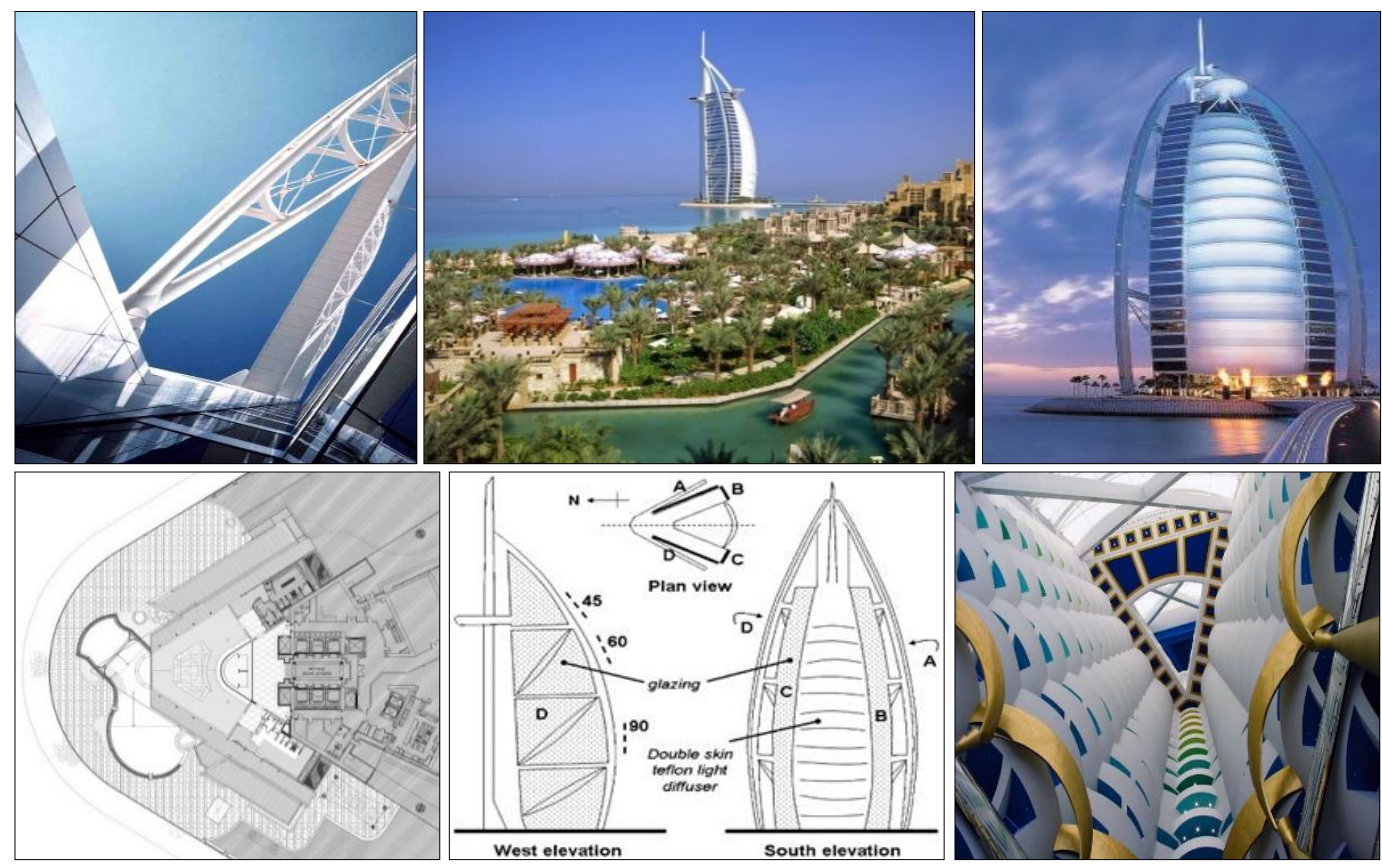

Figure 1: Images for $\mathrm{Al}$ Arab tower Building in Dubai [27].

\subsubsection{Khalifa Tower in Dubai, United Arab Emirates, by Adrian Smith, Owings and Merrill SOM}

Khalifa Tower is the tallest building in the world, also the tallest tower in the world, at 828 meters high, it breaks many records of altitude. The construction of this tower began in the Emirate of Dubai in the United Arab Emirates on 6 January 2004. The external structure has completed on 1 October 2009 and officially opened on 4 January 2010, becoming the world's tallest building instead of the Taipei 101 tower in Taiwan. The tower was built by Emaar Company, and it is built of reinforced concrete. The building was opened in 2010, as part of a development called Downtown Dubai. It is designed to be a large-scale, versatile hub. The decision to build the building was based on the government's decision to diversify from an oil-based economy, and to be a global destination. The tower was named in honor of the ruler of Abu Dhabi and the President of the United Arab Emirates, Khalifa Bin Zayed Al Nahyan. The Tower design derives from the profiling systems embodied in Islamic architecture, which includes cultural and historical elements, especially in this region, such as a twisted minaret. The Y-shaped plan is designed for residential and hotel use. The structural system has adopted in the construction in order to support the large rise of the building. The exterior cladding system aims to withstand the high summer temperatures in Dubai. The building has a total of 57 elevators with a capacity of 12 to 14 people, in addition to 8 escalators. Designed to represent a distinctive visual point in the city as the tallest building in the world, it has been planned as the hub of a new urban area within Dubai. This is the most exaggerated representation of urban development through the creation of commercial structures to replace traditional monument buildings. As well as the over-exploitation of the architectural aspect and marketing tools, to raise the value of properties surrounding the building. The surrounding areas have treated in an unconventional way through the views surrounding the tower, carefully designed within an industrial village that greatly increases its monumental. Figure 2 shows photos for Burj Khalifa in Dubai. 


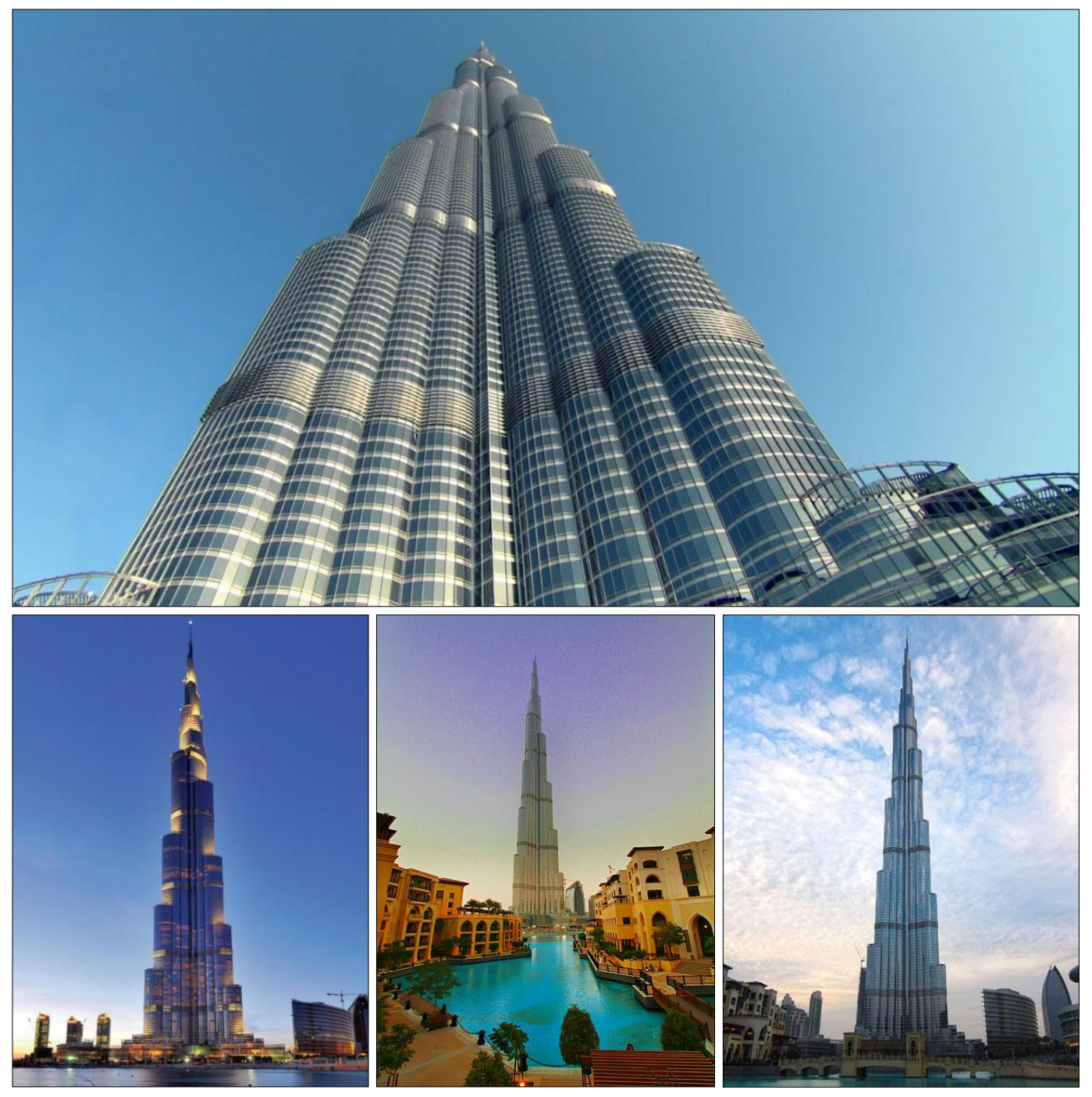

Figure 2: Photos for Khalifa Tower in Dubai [27].

\subsubsection{Second Group - World Projects}

\subsubsection{Pompidou Center in Paris}

In 1970, architects Renzo Piano and Richard Rogers, both were unknown at that time, collaborated to design one of the most famous buildings and towers of our modern era, the center of Georges Pompidou, which is the cultural center in Paris. The story of the construction of this building began in the era of George Pompidou, President of the Republic of France from 1969 to 1974, who wanted to build a completely new cultural center in Paris which would attract visitors and be a new symbol of the city. In order to choose the project designer, the President announced a competition for the design of the multidisciplinary center, which has involved by many architects, including the most famous architects of that time. People have very impressed that the design of Renzo Piano and Richard Rogers, as they have not known at that time, was the winner. Their design has an example of high architecture and technology, a modern cultural center build with a system of structural supports unparalleled in any architectural work in the world before. Their design idea, as presented in one of their drawings of the competition, represent the museum itself as a movement. The other idea in their design, perhaps the most obvious, has to show the entire infrastructure of the building, as the mechanical and structural systems showed. It has not only an idea, but it has a benefit of increasing the interior space without distractions. The various infrastructure systems on the exterior of the building have painted in different colors to distinguish between their different roles. The structural and large ventilation elements have painted with white color. while staircases and lifts in silver gray, blue for ventilation, plumbing pipes and firefighting pipes have painted with green, electric elements in yellow and orange, elevator rooms or elements that allow movement around the building generally in red. One of the movement's most famous elements is the escalator (red painted on the bottom part) on the western façade, the tube that reaches the top of the building and offers visitors a stunning view of the beautiful city of Paris. The center also houses the Musee National Museum of Modern Art, the largest museum of modern art in Europe. It is also located in the vast open-air area within the General Information Office, the Music and Sound Research Center (IRCAM) and the open-air arena, 
a permanent arena that welcomes various local events, and officially opened on January 31, 1977, as a movement and an observatory for the city to see its daily life. Figure 3 shows pictures of the Pompidou Center in Paris [29].
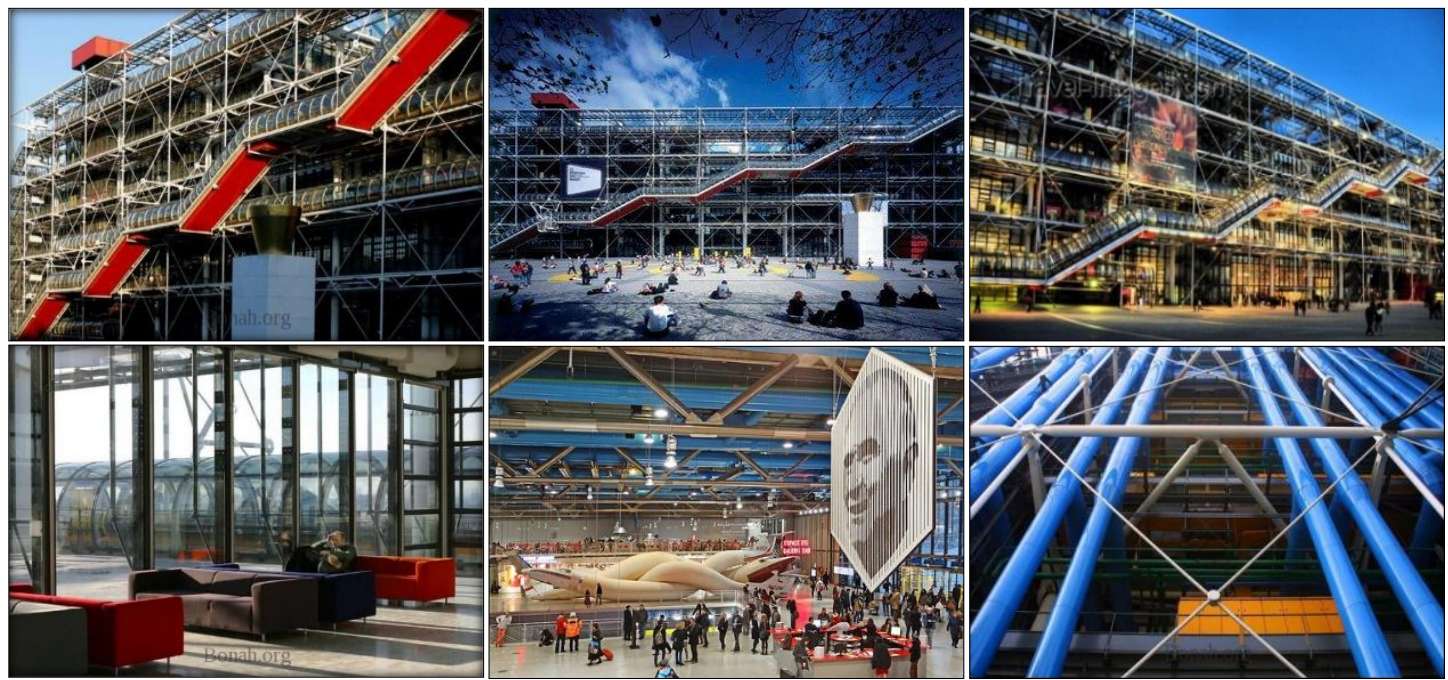

Figure 3: Photos for Pompidou Center in Paris [28]
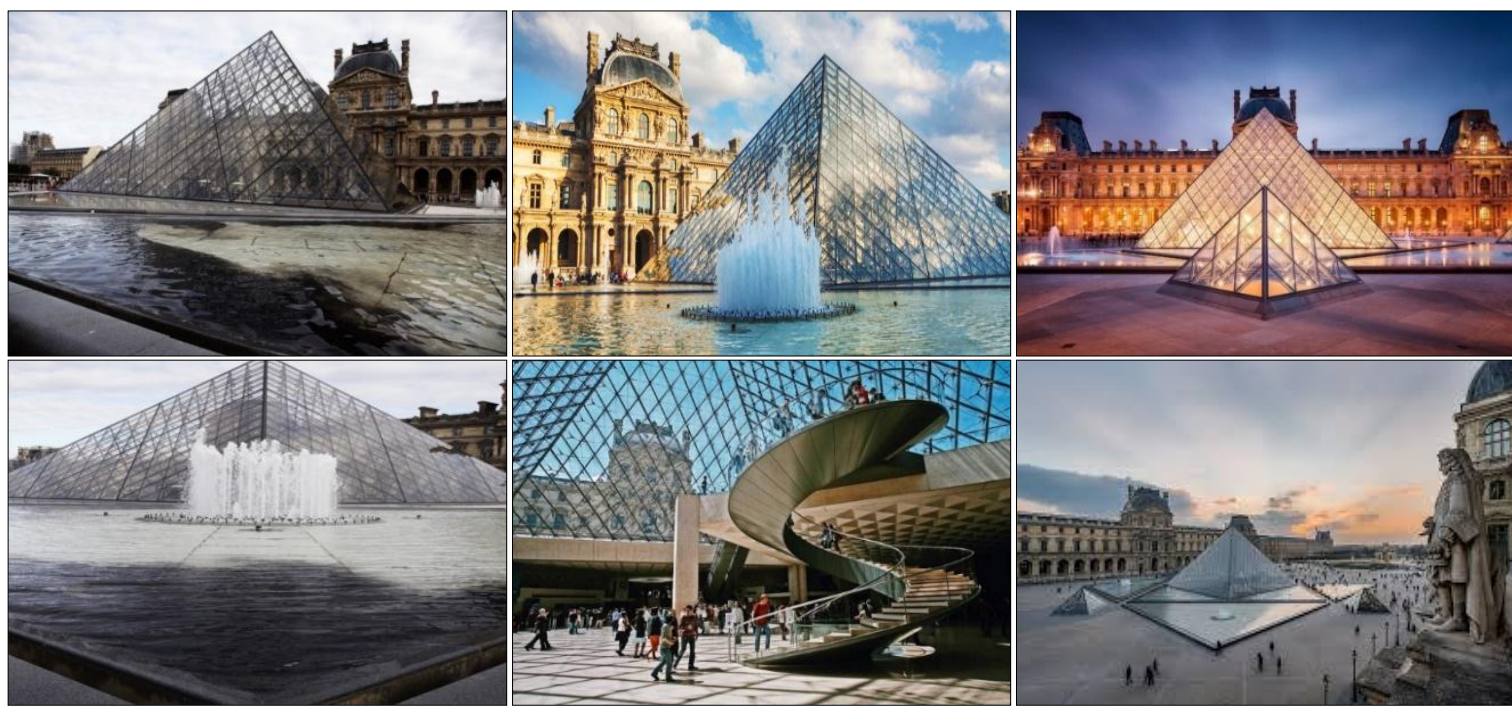

Figure 4: Photos for Louvre Museum [31].

\subsubsection{The Louvre Museum Project in Paris}

The project has promised one of the most controversial 20th century projects among architects for reasons that have clearly differentiated by the state of description. The Louvre Palace has the seat of the highest political authority in France. The architect Claude Perrault expressed this power by dominating the classical eastern façade built during the reign of Louis Fourteenth and two sides were added. The glass pyramid is the largest element in the Louvre, and the transformation of the Louvre from a headquarters of political power to a center through which French cultural heritage can be traced. This form, through its purity and centrality, calls for a clear correlation between the French gardens, This crystal pyramid is an impression of the Louvre as a repository of treasures. It also refers in great measure to the period of the end of the eighteenth century, and it may be said to refer the victory of Napoleon Bonaparte in Egypt, ie, the restoration of the French glories [30]. Figure 4 shows pictures of the Louvre building in Paris.

here the signature of the pyramid at the height of the metaphorical axis that crosses the Arc de Triomphe, which France considers a symbol of the strength of its history, culture and art and not only armies, and here we find that the glass pyramid lying on top parade of French celebrations, this project is understood in the light of the 
foundations of disintegration as a struggle for the presence and eternity (historical, formal and formal), in the case of conflict in order to prove the presence and identity of each. As such, it is not important to preserve the museum in its physical condition, but to emphasize the continuing creative achievement of French art and culture [32]. "The project, like continuing life, must have a positive impact on the life of the city. The displacement of earlier meanings associated with the same forms and the reflective implications of what previous buildings attempted to do in their time has attempted to achieve the eternal presence of identity as part of the city's traditions and living symbols [32].

\section{Ruslts Discussion and Analysis}

In the previous paragraph, a set of selected projects has put forward for the application. In this paragraph, the indicators that have been marked for each project will be interrogation according to the specific theoretical framework. The results of the application have been classified as strong, relatively strong, moderate or weak. These indicators are summarized in table (2) according to the critical investigation of the description presented in addition to the formal indicators of each image of the output, which explains in detail the achievement of the main and secondary vocabulary in the selected samples as follows:

Table (2): Vocabularies of Theoretical framework and Results of Application

\begin{tabular}{|c|c|c|c|c|c|c|c|c|c|}
\hline \multirow{3}{*}{$\begin{array}{c}\text { Main } \\
\text { vocabulary }\end{array}$} & \multirow{3}{*}{\multicolumn{2}{|c|}{ Secondary vocabulary }} & \multirow{3}{*}{ Symbol } & \multicolumn{5}{|c|}{$\begin{array}{c}\text { Verification in the } \\
\text { selected samples }\end{array}$} & \multirow{3}{*}{$\begin{array}{l}\text { Discussing } \\
\text { results for } \\
\text { qualitative } \\
\text { analysis }\end{array}$} \\
\hline & & & & \multicolumn{2}{|c|}{$\begin{array}{l}\text { First } \\
\text { group }\end{array}$} & \multicolumn{2}{|c|}{$\begin{array}{l}\text { Second } \\
\text { group } \\
\end{array}$} & \multirow{2}{*}{$\begin{array}{l}\text { Total } \\
\text { verifie } \\
\quad \text { d }\end{array}$} & \\
\hline & & & & 1 & 2 & 3 & 4 & & \\
\hline \multirow{5}{*}{$\begin{array}{c}\text { The } \\
\text { meaning of } \\
\text { the } \\
\text { architectur } \\
\text { al image } \\
\text { X.1 }\end{array}$} & \multicolumn{2}{|c|}{ Shape or Form } & X.1.1 & $\checkmark$ & $\checkmark$ & $\checkmark$ & $\checkmark$ & 4 & strong \\
\hline & \multicolumn{2}{|c|}{ Compositional structure } & X.1.2 & $\checkmark$ & & $\checkmark$ & $\checkmark$ & 3 & $\begin{array}{l}\text { relatively } \\
\text { strong }\end{array}$ \\
\hline & \multicolumn{2}{|c|}{ Collection for items and pieces } & X.1.3 & $\checkmark$ & $\checkmark$ & $\checkmark$ & & 3 & $\begin{array}{l}\text { relatively } \\
\text { strong }\end{array}$ \\
\hline & \multirow{2}{*}{\multicolumn{3}{|c|}{ Total for X.1 }} & 3 & 2 & 3 & 2 & \multirow{2}{*}{$10 / 12$} & \multirow{2}{*}{ strong } \\
\hline & & & & \multicolumn{2}{|c|}{5} & \multicolumn{2}{|c|}{5} & & \\
\hline \multirow{7}{*}{$\begin{array}{c}\text { Sources of } \\
\text { building the } \\
\text { architectur } \\
\text { al image } \\
\text { X.2 }\end{array}$} & \multirow{3}{*}{$\begin{array}{l}\text { Mental } \\
\text { perception } \\
\text { X.2.1 }\end{array}$} & Drawing mental maps & X.2.1.1 & $\checkmark$ & & & & 1 & moderate \\
\hline & & $\begin{array}{l}\text { Moving from sense to } \\
\text { mental image building }\end{array}$ & X.2.1.2 & & & & $\checkmark$ & 1 & moderate \\
\hline & & $\begin{array}{l}\text { Using Imagism and } \\
\text { expressive signals }\end{array}$ & X.2.1.3 & $\checkmark$ & $\checkmark$ & $\checkmark$ & & 3 & $\begin{array}{l}\text { relatively } \\
\text { strong }\end{array}$ \\
\hline & \multirow[t]{2}{*}{$\begin{array}{l}\text { Sensual } \\
\text { perception } \\
\text { X.2.2 }\end{array}$} & $\begin{array}{l}\text { Perceiving the clarity of } \\
\text { the physical elements of } \\
\text { the city }\end{array}$ & X.2.2.1 & $\checkmark$ & $\checkmark$ & & $\checkmark$ & 3 & $\begin{array}{l}\text { relatively } \\
\text { strong }\end{array}$ \\
\hline & & Creative Ideas & X.2.2.2 & & $\checkmark$ & $\checkmark$ & & 2 & moderate \\
\hline & \multirow{2}{*}{\multicolumn{3}{|c|}{ Total for X.2 }} & 3 & 3 & 2 & 2 & \multirow{2}{*}{$10 / 20$} & \multirow{2}{*}{ moderate } \\
\hline & & & & \multicolumn{2}{|c|}{6} & \multicolumn{2}{|c|}{4} & & \\
\hline \multirow{6}{*}{$\begin{array}{c}\text { functional } \\
\text { dimensions } \\
\text { for building } \\
\text { the } \\
\text { architectur } \\
\text { al image } \\
\text { X.3 }\end{array}$} & \multicolumn{2}{|c|}{ Spatial dimension } & X.3.1 & $\checkmark$ & & & $\checkmark$ & 2 & moderate \\
\hline & \multicolumn{2}{|c|}{ Formative dimension } & $\mathbf{X . 3 . 2}$ & $\checkmark$ & $\checkmark$ & & & 2 & moderate \\
\hline & \multicolumn{2}{|c|}{ Compositional dimension } & $\mathbf{X . 3 . 3}$ & $\checkmark$ & & $\checkmark$ & $\checkmark$ & 3 & $\begin{array}{l}\text { relatively } \\
\text { strong }\end{array}$ \\
\hline & \multicolumn{2}{|c|}{$\begin{array}{l}\text { Applied dimension (diagnostic } \\
\text { quality) }\end{array}$} & X.3.4 & & & & $\checkmark$ & 1 & weak \\
\hline & \multirow{2}{*}{\multicolumn{3}{|c|}{ Total for X.3 }} & 3 & 1 & 1 & 3 & \multirow{2}{*}{$8 / 16$} & moderate \\
\hline & & & & 4 & & & & & \\
\hline The & & $\begin{array}{l}\text { Position within the city } \\
\text { plan }\end{array}$ & X.4.1.1 & & $\checkmark$ & $\checkmark$ & & 2 & moderate \\
\hline $\begin{array}{l}\text { components } \\
\text { of building }\end{array}$ & General & $\begin{array}{l}\text { Main assembly points in } \\
\text { the city }\end{array}$ & X.4.1.2 & $\checkmark$ & & & & 1 & weak \\
\hline $\begin{array}{l}\text { the } \\
\text { architectur }\end{array}$ & $\begin{array}{l}\text { components } \\
\text { X.4.1 }\end{array}$ & $\begin{array}{l}\text { Building materials and } \\
\text { construction methods }\end{array}$ & X.4.1.3 & $\checkmark$ & $\checkmark$ & $\checkmark$ & & 3 & $\begin{array}{l}\text { relatively } \\
\text { strong }\end{array}$ \\
\hline $\begin{array}{c}\text { al image } \\
\text { X.4 }\end{array}$ & & $\begin{array}{c}\text { Characteristics of } \\
\text { architectural elements of } \\
\text { the city }\end{array}$ & X.4.1.4 & & $\checkmark$ & $\checkmark$ & $\checkmark$ & 3 & $\begin{array}{l}\text { relatively } \\
\text { strong }\end{array}$ \\
\hline
\end{tabular}




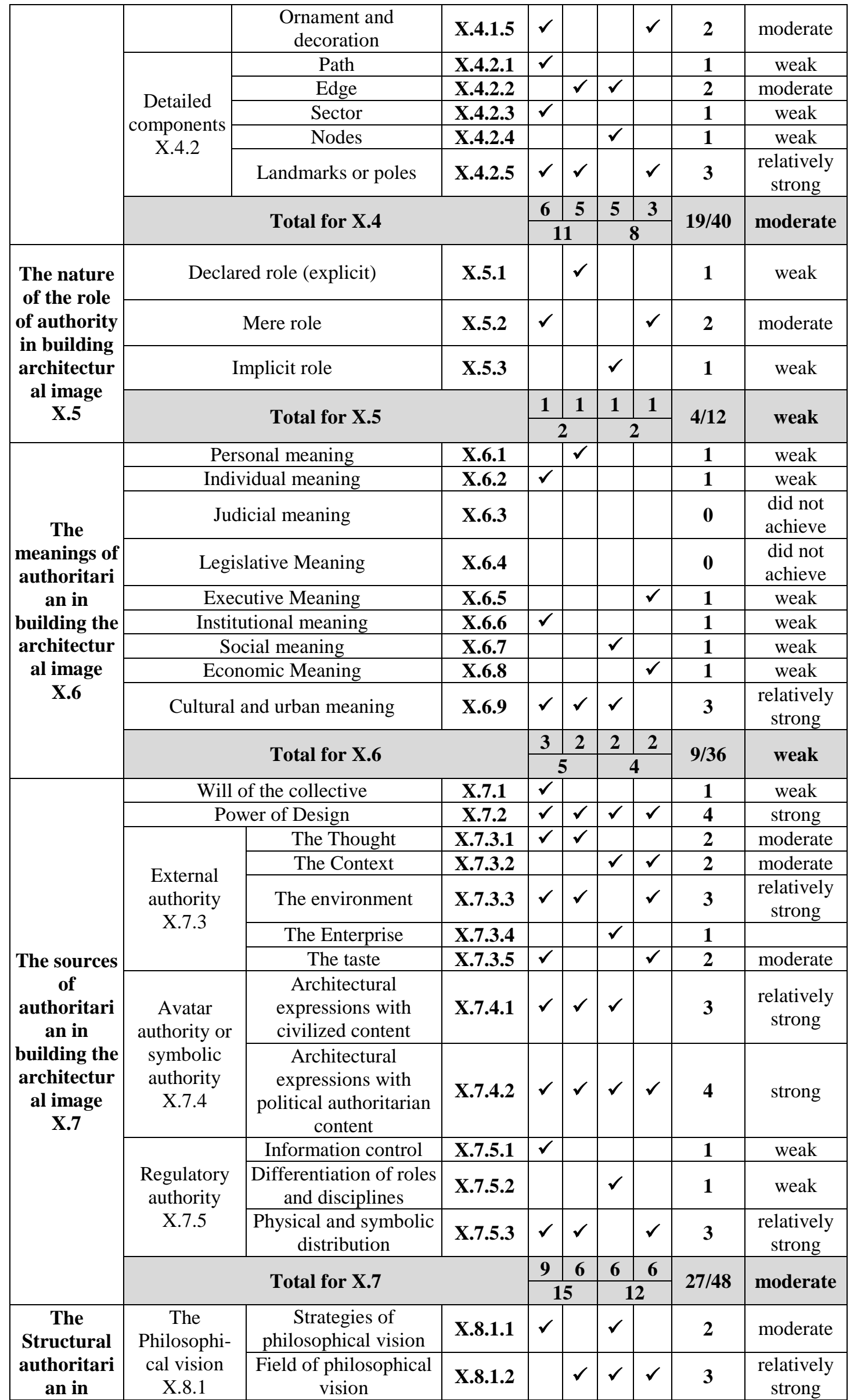




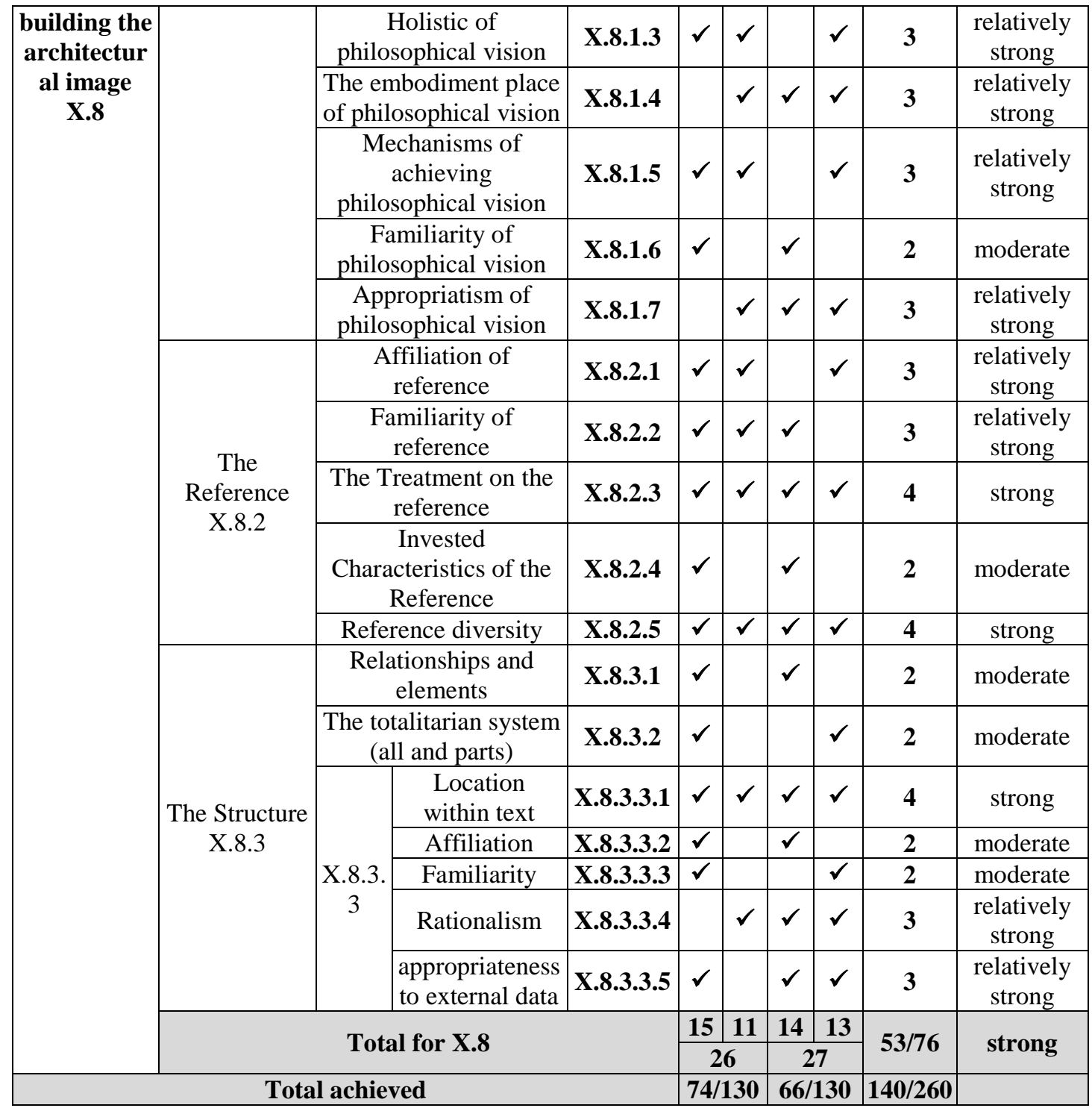

\section{Conclusions}

\subsection{Conclusions for Theoretical Framework}

- The architectural image is the shape, form or structure in which the city emerges. Which is produced by the process for collecting the elements, parts and vocabulary by the process of either sensual perception (through realizing of the clarity of the physical elements in the city, like paths, bridges, sections, nodes, landmarks or signs, just as seen by naked eye), or the mental perception (through the light of mental mapping and moving from the sense to build the image of the thing in mind, on the basis of the use of pictorial and expressive signals that convey meanings to mind and in more integrated form and expansion in comprehension of images and comprehensiveness of meanings and shapes.

- The role of political power for building the architectural image is either declared (explicit), or implicit by influencing planning, management, governance, economy, architectural thought and guiding social and cultural issues. Political authoritarian fluctuations have a role in adding new meaning to history and a new perception of society and a new body or structure of the city, with the aim of bringing something out to the real existence, and emphasizing the architecture based on tradition, context, environment, history, or other qualities that change the structure of the city, the visible or the latent one, which is a bigger and stronger challenge than the control and domination of the adventurers of architecture makers.

- The influence of political power with or without an intentional goal in the general taste of the category has governed by the conscious imitation of the vocabularies, forms and relationships, also the process of the effect of unconsciously produce replicable models in different places vary between them in terms of quotation and imitation to form a launch of the architectural identity, which symbolizes that era.

- The process of selecting formal references and their association with inheritance (both from inside and outside architecture) by the political authority is influenced the extent of which the governed (the people) 
know these references in thought and content, and thus to know that period of history in form and substance.

\subsection{Conclusions for Application}

- The selected projects have highlighted the importance of the awareness of the ruling authority of the technological leapfrogs at the level of science and knowledge for all disciplines, including architecture. Therefore the need for the authority's to direct the architects to invest that technologies to reflect the evidence of the era, for the rulers and governed groups as well, especially in projects related to the state.

- The selected projects have highlighted the importance of the ruling authority's awareness for what is produced by the technology, and the potential of its investment as a tool to enhance the economic side through the tourist attraction for that country, thus reflecting the psychological comfort and raising the economic side of the individual and society.

- The strong verification of the forms and patterns of authority indicators in terms of (meaning and structural authoritarian), and the moderate verification for (sources, functional dimensions, components, and sources authoritarian). Finally weak verification in for (the role of authority and the authoritarian meanings) in the selected projects for application and the implications of their investment in local experiences of the important role in building the architectural image.

- The clarity of the balance and the moderation of the influence of the types of influences of authority in general on the level of measurement of vocabulary and projects. While for the groups they tend to influence (the influence of the ruling authority) more strongly in the Arabic group to reflect their role in building architectural image, and this corresponds to the state of intellectual and theoretical trends of those communities, and active style in the formation of its distinctive civilization structure. That is because authority is one of the main factors influencing the formation of its identity of architecture, and building its architectural image.

\section{Recommendations}

- The research recommends that the influence of the political authority shall be invested in building a clear image of the city at the local level, by directing the decision makers and the authority to adopt a set of different models of functions (hotels, museums, cultural centers, administrative towers, etc.). The local heritage also shall be invested as a basis for this intellectual and formal construction and takes into account the potential of advanced technology at all times and places.

- The research recommends that the students and engineers of architecture shall focus on building the symbolic side in parallel to the form construction, to create images that excited the feelings of the recipient, which will be reflected positively on the knowledge of the ruler and the people about the importance of those inherited values, and what will result of simulated copies for the origin copies in a contemporary manner.

- The study recommends the need to expand the study of the extent of the impact of the ministries of the state in building the image of the city, and what the duties of each, which can contribute to highlighting the general interconnections between these ministries, and the diagnosis the positives and negatives.

- The research recommends the need to study the possibility of the existence of other cognitive, intellectual and practical forms concerning with general interconnections that affect the image-building of architecture in the city, and the possibility of investing them, with other forms that already had explained, in course of the design function

\section{References}

[1] Hatem, Wadhah Amer "Comparing Design Quality for School Buildings in Iraq" Diyala Journal of Engineering Sciences, Vol. 07, No. 01, March 2014, p. 119.

[2] Abdul Jalil, Raad, "The Concept of Political Power: Contribution to the Study of Political Theory", Journal of International Studies (Baghdad), Issue (37), 2008, p.121.

[3] The Arabian International.Encyclopedia, Foundation of the Encyclopedia for Publishing and Distribution works, 1996, part 13, p.55.

[4] Al-Taher, Laqus Ali, "The Symbolism of Pierre Bourdieu", Academic of Social and Human Studies, B / Department of Arts and Philosophy, No. 16, June, 2016, p.41.

[5] Best, S. "Power, authority, and the state. In Introduction to Politics and society", (pp. 6-39). Thousand Oaks, CA: Sage Publications, 2002.

[6] Williams, Dana, "Max Weber: Traditional, LegalRational, and Charismatic Authority", The University of Akron, Akron Ohio, 2003, p2.

[7] http://www.merriamwebster.com/dictionary/policy,25-8-2017

[8] http://fcdrs.com/mag/issue-6-2.html

[9] Rushdi, Shirin, "The Political Fluctuations between urbanism of architecture and its anarchy", Tarek Wali Amara and Heritage Center's newspaper, March 2015, p.1.

[10] Waqee'a Allah, Dr. Ahmad, "Introduction to Political Philosophy: An Islamic Perspective," Dar Al-Fikr, Damascus, (ISBN: 978-9933-10-113-8), 2010.

[11] Kassab, Maroun "Architecture between Politics and Civilization", https://newspaper.annahar.com/article/12847, April 2014, pp.1-3.

[12] Arnhim, Alexander Von "Image the City" MSC course in advanced architectural studies, London 1987, p.47.

[13] Greza, Abbas Ali, "Symbolism as a strategy of continuity in contemporary architecture", $\mathrm{PhD}$ thesis, Department of Architecture, University of Technology, 2005, pp.37-38. 
[14] Kareem, Khawla, "The Visual Image of the Cities of the Future", Master Thesis submitted to the Department of Architecture at the University of Technology, 2014, p.12.

[15] Lynch, Kevin, "The Image of the City", Cambridge, London, England 1996, p.46.

[16]Carmona Matthew, Heath Tim \& Tiesdell Steven, "Public places urban spaces", Gillingham, Kent, UK Printed and bound in Great Britain, 2003, pp.88-90.

[17] Al-Obaidi, Dargham Mezher Karim, "The Impact of Politics on the Thought of Architecture, an Analytical and Descriptive Study of the Influence of Political Ideology on Achievement of Architecture, Berlin City as a Model", Volume 18, Issue 11, November, 2012, Journal of Engineering, University of Baghdad, pp.255-260.

[18] Kassab, Maroun, op cit, 2014, pp.1-3.

[19] A. Pestoff, Victor, "A Democratic Architecture for the Welfare State", USA and Canada, 2009.

[20] Sylvain de Bleeckere, Universities' Hasselt, "Style and Architecture in a Democratic Perspective", ARCC Journal/ Volume 4 Issue 1, DOI 10.17831/enq: arcc.v4i1.51, 2007.

[21] Al-Obaidi, op cit, pp.255-260.

[22] Rashid, Ahmed Yahya Jamal Al-Din, "Architectural Education Between Preservation of Identity and the Political Dimension: A Study of the Course of History and theories of Architecture from the Beginning of Human Civilizations to the Era of Globalization", Symposium on Engineering Education in the Arab World, Arab Engineers Union, 9/2003, p.12.

[23] Hassanein, Imad Mohamed and others, "Political Transformations and Their Impact on the Architectural Character of Administrative Buildings in Egypt - A Case Study of Administrative Buildings in Egypt during the 20th Century", Journal of Engineering Sciences, Assiut University, Volume 43 Issue 4, July, 2015.

[24] Dovey, Peter "The Architecture Review", Middle East, London, issue4, spring, 2000, p.28.

[25] Al-Khayat, Mahmoud Ahmad, "Studying Architecture as a Language"; Master's thesis, Architectural Engineering, University of Technology, Baghdad, 1995 , p.88.

[26] http://en.wikipedia.org/wiki/Burj_Al_Arab

[27] https://en.wikipedia.org/wiki/Burj_Khalifa

[28] https://www.archdaily.com/64028/ad-classics-centregeorges-pompidou-renzo-piano-richard

[29] Byard, Paul Spencer, "The Architecture of Additions Design and Regulation", W.W.Norton and company, New York, 1998, pp.67-70.

[30] https://www.centerpompidiou.Fr/en/The-CenterPompidou\#130s

[31] https://fr.wikipedia.org/wiki/Mus\%C3\%A9e_du_Lou vre

[32] Mugerauer, Robert, Deride and Bevond "Theorizing a new Agenda for Architecture; Anthology of Architectural Theory 1965-1995", Nesbitt, Princeton Architectural press, New York, 1996, p.193. 